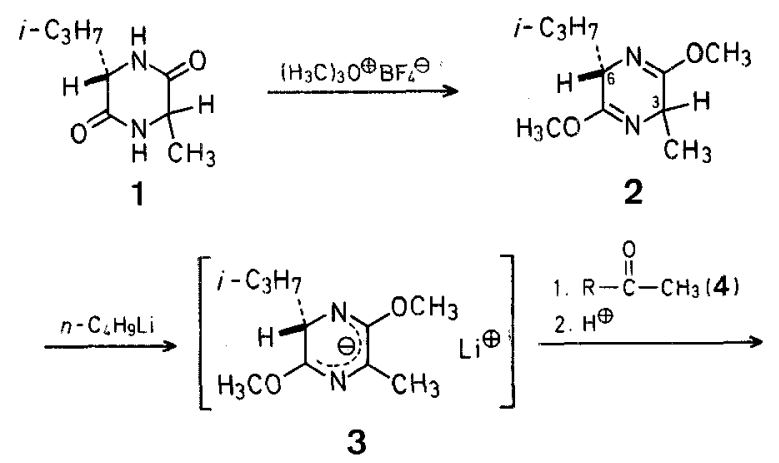

\section{Asymmetric Syntheses via Heterocyclic Intermediates; XIII'. Enantioselective Synthesis of $(R)-\alpha-$ Alkenylalanine Methyl Esters using L-Valine as Chiral Auxiliary Reagent}

\section{Ulrich GROTH, Ulrich SCHÖLlKOPF, YAO-CHUNG CHIANG}

Institut für Organische Chemie der Universität Ciöttingen, Tammannstraße 2, D-3400 Göttingen, Federal Republic of Germany

As reported earlier ${ }^{2}$, alkyl halides react with the lithiated bislactim ether 3 [obtained from cyclo(L-Val-D,L-Ala) (1)] with d.e. $(=$ diastereomeric excess $=$ asymmetric induction $)>95 \%$. As we have found now, carbonyl compounds (4) such as acetone, acetophenone, or acetaldehyde react with 3 also with d.e. $>95 \%$ to give the $(3 R)$-configurated aldol-type adducts 5 . The diastereomeric purity of 5 was established ${ }^{1}$ H-N.M.R.spectroscopically using $\mathrm{Eu}(\mathrm{fod})_{3}$ as shift reagent, whereby the methyl singlets could be used for the analysis, or ${ }^{13} \mathrm{C}$-N.M.R.spectroscopically, whereby the $\mathrm{C}-3^{\prime}$-signal could be used. In neither case could the diastereoisomer with the $(3 S)$-configuration be detected. The $(3 R)$-configuration of $\mathbf{5 b}$ was deduced from the ${ }^{1}$ H-N.M.R.-spectrum. According to our experience ${ }^{3}$, bis-lactim ethers of the type 5 adopt a boat shape for the heterocycle and the "folded conformation" for the hydroxybenzyl group (cf. A for 5b). Hence, the signal of 6-H suffers an upfield shift ${ }^{4}$. By analogy we assume the $(3 R)$-configuration also for $5 \mathbf{a}$ and $\mathbf{5 c}$.

As expected, the enantioface differentiation at the carbonyl group is weaker. C-3' Induction amounts to $\sim 5 \%$ for $\mathbf{5 b}$ and $\sim 65 \%$ for $5 \mathrm{c}$.

As for the mechanism of carbonyl addition, we postulate the transition state B which is stabilized by HOMO(anion)-LUMO(carbonyl)-attraction (cf. Ref. ${ }^{3}$ ) and by the chelating power of lithium ${ }^{5}$. Due to the bulky isopropyl group at C-6, "bottom side attack" is lavored (cf. B).

The adducts 5a and $\mathbf{5 b}$ were dehydrated to the olefinic compounds 6 by treatment with thionyl chloride/pyridine and compounds 6 were hydrolyzed with 0.25 normal hydrochloric acid to give $\mathrm{L}-\mathrm{Val}-\mathrm{OCH}_{3}$ and $(2 R)$ methyl 2-amino-2,3-dimethyl-3-butenoate (8a) or (2R) methyl 2-amino-2-methyl-3-phenyl-3-butenoate (8b) $(\alpha$-methyl- $\beta$-methylenephenylalanine methyl ester ${ }^{6}$ ). Both compounds were enantiomerically pure by N.M.R. standard [Eu(hfc $\left.)_{3}\right]$.

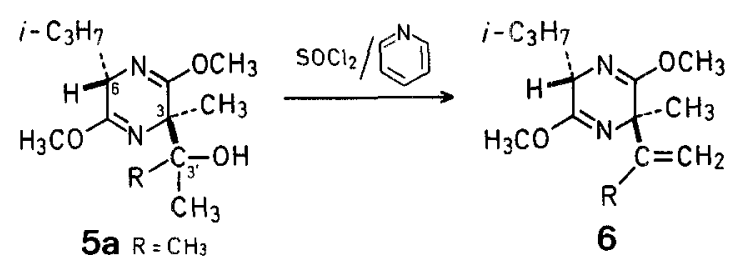

5a $\mathrm{R}=\mathrm{CH}_{3}$

$5 \mathbf{b} \mathrm{R}=\mathrm{C}_{6} \mathrm{H}_{5}$

$5 C R=H$<smiles>[R]C(=C)C(C)(N)C([R])(C)C([R])=CC([R])(N)C(C)(N)C(C)=O</smiles>

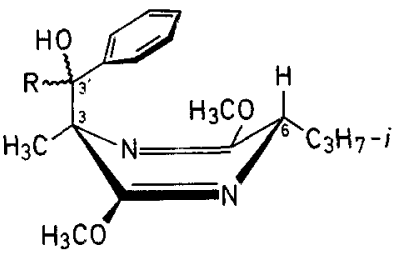

A.

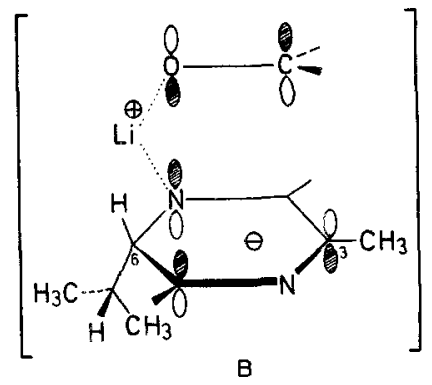

B
The acetaldehyde adduct $\mathbf{5 c}$ was $\boldsymbol{O}$-methylated and the resultant 5d hydrolyzed to a $4.5: 1$ diastereomer mixture $[(2 R, 3 S)$ and $(2 R, 3 R)]$ of methyl 2-amino-3-methoxy-2-methylbutanoate (9), enantiomerically pure at C-2 (the preferred configuration at $\mathrm{C}-3$ was not determined).<smiles>CCCC[C@H]1N=C(OC)[C@@](C)(C(C)OC)N=C1OC</smiles>

Bis-lactim ether $2^{2}$ was prepared as reported.

Aldol-Type Adducts 5a, b:

A 1.55 normal solution $(3.6 \mathrm{ml}, 5.5 \mathrm{mmol})$ of butyllithium in hexane is added by syringe to a stirred solution of compound $2(0.99 \mathrm{~g}, 5 \mathrm{mmol})$ in tetrahydrofuran $(10 \mathrm{ml})$ at $-70^{\circ} \mathrm{C}$. After $15 \mathrm{~min}$, a solution of the carbonyl compound $4(5.5 \mathrm{mmol})$ in tetrahydrofuran $(5 \mathrm{ml})$ is added and stirring is continued for $2-3 \mathrm{~h}$ at $-78^{\circ} \mathrm{C}$. Then, a solution of glacial acetic acid $(0.33 \mathrm{~g}, 5.5 \mathrm{mmol})$ in tetrahydrofuran $(2 \mathrm{ml})$ is added. The solvent is removed in vacuo and the residue shaken with ether $(10-15 \mathrm{ml})$ and water $(20 \mathrm{ml})$. The layers are separated and the aqueous layer is extracted with ether $(2 \times 10 \mathrm{ml})$. The ether extract is dried with magnesium sulfate, the solvent evaporated, and the residual product distilled in vacuo. 
Table 1. Aldol-Type Adducts 5

\begin{tabular}{|c|c|c|c|c|c|c|}
\hline 5 & $\mathbf{R}$ & $\begin{array}{l}\text { Yield } \\
{[\%]}\end{array}$ & $\begin{array}{l}\text { b.p. } \\
{\left[{ }^{\circ} \mathrm{C} / \text { torr }\right]}\end{array}$ & $\begin{array}{l}\text { d.e. } \\
\text { C-3 } \\
\left(C-3^{\prime}\right)\end{array}$ & $\begin{array}{l}\text { Molecular } \\
\text { formula }\end{array}$ & $\begin{array}{l}\text { 'H-N.M.R. }\left(\mathrm{TMS}_{\text {ini }}\right) \\
\delta[\mathrm{ppm}]\end{array}$ \\
\hline a & $\mathrm{CH}_{3}$ & 94 & $60-70^{\circ} / 0.1$ & $>95$ & $\begin{array}{l}\mathrm{C}_{13} \mathrm{H}_{24} \mathrm{~N}_{2} \mathrm{O}_{3} \\
(256.3)\end{array}$ & $\mathrm{CDCl}_{3}: 0.72,1.13(2 \mathrm{~d}) ; 1.10,1.40(2 \mathrm{~s}) ; 1.28(\mathrm{~s}) ; 3.99(\mathrm{~d}, 6 \mathrm{H})$ \\
\hline b & $\mathrm{C}_{6} \mathrm{H}_{5}$ & 93 & $110-120^{\circ} / 0.05$ & $\begin{array}{l}>95 \\
(\approx 5)\end{array}$ & $\begin{array}{l}\mathrm{C}_{18} \mathrm{H}_{26} \mathrm{~N}_{2} \mathrm{O}_{3} \\
(318.4)\end{array}$ & $\begin{array}{l}\mathrm{CDCl}_{3} / \mathrm{C}_{6} \mathrm{H}_{6}: 0.58,0.60,0.93(3 \mathrm{~d}) ; 1.52(\mathrm{~s}) ; 1.66,1.77(2 \mathrm{~s}) ; 3.02,3.18 \\
(2 \mathrm{~d}, 6-\mathrm{H})^{\mathrm{b}}\end{array}$ \\
\hline c & $\mathrm{H}$ & 85 & $60-70^{\circ} / 0.05$ & $\begin{array}{l}>95 \\
(\approx 65)\end{array}$ & $\begin{array}{l}\mathrm{C}_{12} \mathrm{H}_{22} \mathrm{~N}_{2} \mathrm{O}_{3} \\
(242.3)\end{array}$ & $\left(\mathrm{DCl}_{3}: 0.73,1.10,0.91(3 \mathrm{~d}) ; 1.17(\mathrm{~d}) ; 1.35,1.45(2 \mathrm{~s}\right.$, epimers $)$ \\
\hline
\end{tabular}

a The microanalyses showed the following maximum deviations from

the calculated values: $\mathrm{C}, \pm 0.14 ; \mathrm{H}, \pm 0.36$.

b ${ }^{13}$ C-N.M.R. $\left(\mathrm{CDCl}_{3} / \mathrm{TMS}_{\text {ist }}\right): \delta=74.11 \mathrm{ppm}(\mathrm{C}-\mathrm{OH})$.

Table 2. (R)- $\alpha$-(1-Alkenyl)-alanine Methyl Esters (8)

\begin{tabular}{llllllll}
\hline 8 & $\mathrm{R}$ & $\begin{array}{l}\text { Yield } \\
{[\%]}\end{array}$ & $\begin{array}{l}\text { b.p. } \\
{\left[{ }^{\circ} \mathrm{C} / \text { torr }\right]}\end{array}$ & $\begin{array}{l}\%^{\mathrm{a}} \\
\text { e.e. }\end{array}$ & $\begin{array}{l}{[\alpha]_{\mathrm{D}}^{20}} \\
(c, \text { ethanol })\end{array}$ & $\begin{array}{l}\text { Molecular } \\
\text { formula }\end{array}$ & $\begin{array}{l}\text { 'H-N.M.R. }\left(\mathrm{CDCl}_{3} / \mathrm{TMS}_{\mathrm{int}}\right) \\
\delta[\mathrm{ppm}]\end{array}$ \\
\hline a & $\mathrm{CH}_{3}$ & $-{ }^{\mathrm{b}}$ & $70-80^{\circ} / 12$ & $>95$ & $-6.2^{\circ}(1.0)$ & $\begin{array}{l}\mathrm{C}_{7} \mathrm{H}_{13} \mathrm{NO}_{2}{ }^{\mathrm{c}} \\
(143.2)\end{array}$ & $1.51(\mathrm{~s}) ; 1.73(\mathrm{~s}) ; 1.82(\mathrm{~m}) ; 3.75(\mathrm{~s}) ; 4.95,5.10(\mathrm{~m})$ \\
b & $\mathrm{C}_{66} \mathrm{H}_{5}$ & 68 & $80-90^{\circ} / 0.1$ & $>95$ & $-28.9(1.2)$ & $\begin{array}{l}\mathrm{C}_{12} \mathrm{H}_{15} \mathrm{NO}_{2}{ }^{\mathrm{d}} \\
(205.2)\end{array}$ & $1.55(\mathrm{~s}) ; 3.70(\mathrm{~s}) ; 5.18,5.45(\mathrm{~s})$
\end{tabular}

\begin{tabular}{|c|c|c|c|}
\hline $\begin{array}{l}\text { Only one enantiomer detectable in the }{ }^{1} \text { H-N.M.R. spectrum using } \\
E u(h f)_{3} \text { as shift reagent. }\end{array}$ & $\begin{array}{l}\text { calc. } \\
\text { found }\end{array}$ & $\begin{array}{r}\text { C } 58.72 \\
58.78\end{array}$ & $\begin{array}{r}\text { H } 9.15 \\
8.95\end{array}$ \\
\hline $\begin{array}{l}\text { Pure 8a was isolated by G.L.C. of the } 7: 3 \text { mixture of } 8 a+7 \text { ob- } \\
\text { tained by bulb-to-bulb distillation. }\end{array}$ & $\begin{array}{l}\text { calc. } \\
\text { found }\end{array}$ & $\begin{array}{r}\text { C } 70.22 \\
70.01\end{array}$ & $\begin{array}{r}\text { H } 7.33 \\
7.69\end{array}$ \\
\hline
\end{tabular}

The crude products 5a, b were analyzed for diastereoisomeric purity by ${ }^{1} \mathrm{H}$-N.M.R. with $\mathrm{Eu}(\mathrm{fod})_{3}$ using the $\mathrm{CH}_{3}$-singlets and by ${ }^{13} \mathrm{C}$ N.M.R. using the $\mathrm{C}-\mathrm{OH}$ signal.

(R)- $a$-(1-Alkenyl)-alanine Methyl Esters (8a, b):

(3R,6S)-2,5-Dimethoxy-3-isopropenyl-6-isopropyl-3-methyl- (6a) and (3R,6S)-2,5-Dimethoxy-6-isopropyl-3-methyl-3-(1-phenylvinyl)-3,6-dihydropyrazine (6b): A solution of compound $5(1.0 \mathrm{~g}$ of $5 \mathrm{a}$ or $1.27 \mathrm{~g}$ of $5 \mathrm{~b}$ as an epimer mixture, $4 \mathrm{mmol})$ and pyridine $(1.26 \mathrm{~g}, 16 \mathrm{mmol})$ in toluene $(10 \mathrm{ml})$ is added to a stirred solution of thionyl chloride $(0.71$ $\mathrm{g}, 6 \mathrm{mmol})$ in toluene $(3 \mathrm{ml})$ at room temperature. Stirring is continued for 2 days and the mixture then shaken with ether $(20 \mathrm{ml})$ and water $(20 \mathrm{ml})$. The layers are separated and the ether layer is dried with magnesium sulfate. The solvent is evaporated and the residual product purified by bulb-to-bulb distillation.

Compound 6a; yield: $0.77 \mathrm{~g}(81 \%)$; b.p. $50-60{ }^{\circ} \mathrm{C} / 0.1$ torr.

Compound $6 \mathrm{~b}$; yield: $1.1 \mathrm{~g}(92 \%) ;$ b.p. $110^{\circ} \mathrm{C} / 0.2$ torr. The product is contaminated by $\sim 10 \%$ of 2,5-dimethoxy-6-isopropyl-3-methylpyrazine.

(R)- $\alpha$-(1-Alkenyl)-alanine Methyl Esters (8a, b): A mixture of compound $6(0.36 \mathrm{~g}$ of $6 \mathrm{a}$ or $0.45 \mathrm{~g}$ of $6 \mathrm{~b}, 1.5 \mathrm{mmol})$ and 0.25 normal hydrochloric acid $(12 \mathrm{ml}, 3 \mathrm{mmol})$ is stirred at room temperature for 4 days. After 24,48 , and $72 \mathrm{~h}$, ether (1-2 $\mathrm{ml}$ each time) is added. The mixture is extracted with ether $(2 \times 5-10 \mathrm{ml})$ and the ether discarded. The water layer is concentrated to 1-2 $\mathrm{ml}$ (in vacuo, maximum bath temperature $\left.60-80^{\circ} \mathrm{C}\right)$, ether $(\sim 10 \mathrm{ml})$ is added, and with vigorous shaking, conc. aqueous ammonia is added till $\mathrm{pH} \mathrm{8-10.} \mathrm{The} \mathrm{ether}$ layer is separated and the water layer extracted with ether $(3 \times 10 \mathrm{ml})$. The ether extracts are dried with magnesium sulfate, the solvent is evaporated, and the residue distilled (bulb-to-bulb). Product 8a is obtained as a $7: 3$ mixture of $8 \mathbf{a}$ and 7 from which pure $8 \mathbf{a}$ can be obtained by G.L.C. (Chromosorb W mesh $60 / 80$, 15\% OV 210). Using Eu(hfc) $)_{3}$ as shift reagent, only one cnantiomer of $8 a, b$ can be detected in the ${ }^{1}$ H-N.M.R. spectrum.
$(2 R, 35)-+(2 R, 3 R)$-Methyl 2-Amino-3-methoxy-2-methylbutanoate (9):

(3R,6S,3'RS)-2,5-Dimethoxy-6-isopropyl-3-(1-methoxyethyl)-3-methyl3,6-dihydropyrazine (5d): A mixture of the 3-(1-hydroxyethyl) compound $5 \mathrm{c}(0.48 \mathrm{~g}, 2 \mathrm{mmol})$, tetrahydrofuran $(10 \mathrm{ml})$, potassium $t$-butoxide $(0.34 \mathrm{~g}, 3 \mathrm{mmol})$, and HMPT $(1.8 \mathrm{~g}, 10 \mathrm{mmol})$ is stirred at $0^{\circ} \mathrm{C}$ for $10 \mathrm{~min}$. Then, a solution of methyl iodide $(0.57 \mathrm{~g}, 4 \mathrm{mmol})$ in tetrahydrofuran is added and stirring is continued for $20 \mathrm{~h}$ at $40^{\circ} \mathrm{C}$. The solvent is removed in vacuo, the residue is dissolved in petroleum ether $(30 \mathrm{ml})$, and this solution is extracted with water $(5 \times 20 \mathrm{ml})$. The organic layer is dried with magnesium sulfate, the solvent evaporated, and the residual product 5d purified by bulb-to-bulb distillation; yield: $0.47 \mathrm{~g}(92 \%) ;$ b.p. $50-60{ }^{\circ} \mathrm{C} / 0.1$ torr (bulb-to-bulb).

$\begin{array}{llrr}\mathrm{C}_{13} \mathrm{H}_{24} \mathrm{~N}_{2} \mathrm{O}_{3} & \text { calc. } & \mathrm{C} 60.91 & \mathrm{H} 9.44 \\ (256.3) & \text { found } & 61.05 & 9.41\end{array}$

'H-N.M.R. ( $\mathrm{CDCl}_{3} / \mathrm{TMS}_{\mathrm{int}}$ ): $\delta=1.21,1.27$ (s, epimers, 3-CH ); 3.29, $3.40 \mathrm{ppm}$ (s, epimers, $3^{\prime}-\mathrm{OCH}_{3}$ ).

(2R,3SR)-Methyl 2-Amino-3-methoxy-2-methylbutanoate (9): A mixture of compound $5 \mathrm{~d}(0.38 \mathrm{~g}, 1.5 \mathrm{mmol}), 0.25$ normal hydrochloric acid ( $12 \mathrm{ml}, 3 \mathrm{mmol})$, and ether $(2-3 \mathrm{ml})$ is stirred at room temperature for 3 days (after 24 and $28 \mathrm{~h}$, the evaporated ether is replaced by $\sim 1$ $\mathrm{ml}$ ether). The mixture is extracted with ether $(2 \times 5 \mathrm{ml})$, the ether phase discarded, and the aqueous phase worked up as described for 8a, b; yield: $0.15 \mathrm{~g}(62 \%)$; b.p. $65-75^{\circ} \mathrm{C} / 0.1$ torr (bulb-to-bulb). The product is a $4.5: 1$ mixture of diastereoisomers.

$\begin{array}{llrr}\mathrm{C}_{7} \mathrm{H}_{15} \mathrm{NO}_{3} & \text { calc. } & \mathrm{C} 52.16 & \mathrm{H} 9.38 \\ (161.2) & \text { found } & 52.28 & 9.43\end{array}$

${ }^{1}$ H-N.M.R. $\left(\mathrm{CDCl}_{3} / \mathrm{TMS}_{\mathrm{int}}\right): \delta=3.30,3.36 \mathrm{ppm}$ ( $2 \mathrm{~s}$, epimers, $\left.\mathrm{OCH}_{3}\right)$. 
Part XII: U. Schöllkopf, J. Neubauer, Synthesis 1982, 861.

2 U. Schöllkopf, U. Groth, K.-O. Westphalen, C. Deng, Synthesis $1981,969$.

3. Schöllkopf, U. Groth, W. Hartwig, Justus Liehigs Ann. Chem. 1981, 2407.

4 Cf. Ref. ; alternatively, in the $(6 S .3 S)$-epimer one of the methyl groups of the isopropyl moiety would lead to an upfield shift. This high-field signal is missing in $\mathbf{5 b}$; cf. U. Groth, Dissertation, University of Göttingen, 1981.

5 This model is similar to the one proposed for the aldol addition: cf: P. Fellmann, J.-E. Dubois, Tetrahedron 34, 1349 (1978).

H. O. House, D. S. Crumrine, A. Y. Teranishi, H. D. Olmstead, J. Am. Chem. Soc. 95, 3310 (1973).

C. H. Heathcock et al., J. Org. Chem. 45, 1066 (1980).

"For an enantioselective synthesis (e.e. $>95 \%)$ of $(R)-\beta$-methylenephenylalanine methyl ester, cf. U. Schöllkopf, U. Groth, Angew. Chem. 93, 1022 (1981); Angew. Chem. Int. Ed. Engl. 20, 977 (1981). 